Ass. Univ. Bull. Environ. Res. Vol. 13 No. 1, March 2010

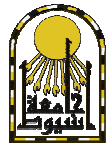

AUCES

\title{
RESPONSE OF SUNFLOWER (HELIANTHUS ANNUUS L.) TO PHOSPHORUS AND NITROGEN FERTILIZATION UNDER DIFFERENT PLANT SPACING AT NEW VALLEY
}

\author{
E.B.A. Osman and M. M. M. Awed
}

Field Crops Res. Institute, A.R.C. Giza, Egypt

\begin{abstract}
:
This investigation was carried out in the New Valley Agricultural Research Station during the summer growing seasons 2007 and 2008 under drip irrigation system to study the effect of phosphorus and nitrogen fertilizer levels and plant spacing on growth, yield and yield components of sunflower (var. Giza 102). The plant spacing of 10, 20 and $30 \mathrm{~cm}$ were used for the study. Phosphorus and Nitrogen levels were 15, 22.5 and $30 \mathrm{~kg} \mathrm{P}_{2} \mathrm{O}_{5}$ fed $^{-1}$ $\& 30,45$ and $60 \mathrm{~kg} \mathrm{~N}$ fed $^{-1}$, respectively.

The obtained results revealed that increasing phosphorus fertilizer levels from 15 to 30 $\mathrm{kg}$ P2O5 fed ${ }^{-1}$ significantly increased all parameters under study. Plant spacing had significant effects on sunflower growth characteristics. The highest plant height seed and oil yields $\mathrm{kg}_{\text {fed }}{ }^{-1}$ obtained from narrow spacing between plants $(10 \mathrm{~cm})$. The highest stem and head diameter, 100-seed weight, seed husk, oil\% and seed yield per plant recorded at wide spacing $(30 \mathrm{~cm})$. Nitrogen application markedly enhanced growth and yield, but resulted in decrease in seed oil percentage. Application of $60 \mathrm{~kg} \mathrm{~N}^{\mathrm{fed}}{ }^{-1}$ produced the highest seed and oil yields fed ${ }^{-1}$.

Considering the superiority of $30 \mathrm{~kg} \mathrm{P}_{2} \mathrm{O}_{5} \mathrm{fed}^{-1}, 10 \mathrm{~cm}$ plant spacing and $60 \mathrm{~kg} \mathrm{~N}$ fed 1 for seed and oil yield, it appears that it could be recommended for producing desirable yield under the New Valley soils conditions.
\end{abstract}

\section{INTRODUCTION:}

Sunflower (Helianthus annuus L.) is an important oilseed crop that ranks the fourth next to soybean, palm oil and canola as a source of edible oil in the world (FAS.USDA, 2008). In Egypt, the cultivated area of sunflower is limited in Nile Valley and the Delta due to the competition with other important summer crops. However, it could be cultivated in newly reclaimed soils in the desert area, which represents about $96 \%$ of Egypt total area. Increasing seed productivity, oil content and oil yield under this area is the major task of research programs.

Phosphorus is an essential element for reproductive plant organs as well as inflorescence, grain formation and ripening. Regarding the effect of phosphorus on sunflower, Jahangir (2006) found that 
maximum number of seeds per head and yield were produced by the application of $75 \mathrm{~kg} \mathrm{P}_{2} \mathrm{O}_{5}$ per hectare.

Plant spacing is among the factors affecting sunflower yield and seed oil percentage. The wide plant spacing enhanced stem diameter, head diameter and seed weight head', while plant height and seed and oil yields fed $^{-1}$ were $^{-1}$ increased with narrow plant spacing (Allam \& Galal, 1996, Basha, 2000, Allam et al., 2003).

Many growers believe that sunflower do not require as much applied fertilizer as cereals. Sunflower has an extensive root system which may help in efficient of residual soil nutrients (Al-Thabet, 2006). Increasing nitrogen rate resulted in increased seed and oil yields/ha (Kasem \& El-Mesilhy, 1992 and Mojiri \& Arzani, 2003).

Recommendations of sunflower planting in the new lands especially under the New Valley conditions are scarce. So, the objective of this work was to investigate the response of sunflower to phosphorus and nitrogen fertilizers and plant spacing under this region.

\section{MATERIALS AND METHODS:}

Two field experiments were carried out at the New Valley Research Station, El-Kharga, New Valley Governorate, Egypt (which is located around the point of $25^{\circ} 27^{\prime} 88.48^{\prime \prime} \mathrm{N}$ latitude and $30^{\circ} 32^{\prime} 43.38^{\prime \prime} \mathrm{E}$ longitude and at 51 m altitude) during 2007 and 2008 summer seasons. These experiments were conducted to study the effect of phosphorus fertilizer levels, plant spacing and nitrogen fertilizer levels on growth, yield and yield components of sunflower var. Giza 102. The texture of the soil of the experimental sites was sandy loam and their mechanical and chemical analysis is given in Table 1.

Table 1: Mechanical and chemical analysis of the experimental soil at the depth of $(0-30 \mathrm{~cm})$ in 2007 and 2008 seasons

\begin{tabular}{||l|c|c||}
\hline \multirow{2}{*}{ Character } & \multicolumn{2}{|c|}{ Season } \\
\cline { 2 - 3 } Sand \% & 2007 & 2008 \\
Silt \% & 71.31 & 72.34 \\
Clay \% & 18.60 & 18.60 \\
Texture & 10.09 & 9.06 \\
pH (1:1 suspension) & Sandy loam & Sandy loam \\
EC (1:1) extract dS m ${ }^{-1}$ & 7.60 & 7.70 \\
CaCO, \% & 0.53 & 0.57 \\
OM \% & 4.30 & 4.45 \\
Total N \% & 0.11 & 0.12 \\
NaHCO - P (mg/kg) & 0.005 & 0.006 \\
Exch. K (meq/100 g soil) & 4.41 & 5.14 \\
\hline
\end{tabular}


Planting dates were May $15^{\text {th }}$ and $17^{\text {th }}$ in 2007 and 2008 growing seasons, respectively. A split plot design with four replicates was used, where the main plots were assigned to the three phosphorus fertilizer levels $(15,22.5$ and $30 \mathrm{~kg}$ $\mathrm{P}_{2} \mathrm{O}_{5}$ fed $\left.^{-1}\right)$. The sub plots were devoted to three plant spacings $(10,20$ and $30 \mathrm{~cm})$ and the subsub plots were assigned to three nitrogen fertilizer levels $\left(30,45\right.$ and $\left.60 \mathrm{~kg} \mathrm{~N}^{\mathrm{N}} \mathrm{fed}^{-1}\right)$. Drip irrigation system was used in these experiments. The drippers of $4 \mathrm{~L} / \mathrm{h}$ discharge were spaced at $50 \mathrm{~cm}$ apart. Each experimental plot contained one line of 18 meters in length and 0.6 apart. Therefore, the area of each experimental plot was $10.8 \mathrm{~m}^{2}$. Plants were thinned to secure one plant/hill after 20 day from planting. The recommended dose of $24 \mathrm{~kg} \mathrm{~K}_{2} \mathrm{O}$ fed $^{-1}$ as potassium sulfate $\left(48 \% \quad \mathrm{~K}_{2} \mathrm{O}\right)$ was applied during the growing season. The nitrogen and phosphorus fertilizers were applied as ammonium nitrate $(33.5 \%)$ and phosphoric acid $(85 \%)$. All fertilizers were splitted into six equal doses. The fertilizers were injected once a week through the irrigation water. Fertigation was started after thinning.

At harvest, 5 guarded plants were taken at random for each plot. Growth characters, yield and its components: plant height $(\mathrm{cm})$, stem diameter $(\mathrm{cm})$, head diameter $(\mathrm{cm})$, 100-seed weight (g), seed husk\%, seed yield plant ${ }^{-1}$, seed

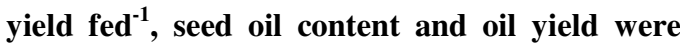
recorded. Seed yield $\mathrm{kg} \mathrm{fed}^{-1}$ was determined from all plants in the plot area $\left(10.8 \mathrm{~m}^{2}\right)$ and converted to one feddan $\left(4200 \mathrm{~m}^{2}\right)$. Oil content of sunflower seeds was determined using
Soxhlet apparatus and Petroleum ether as solvent according to A.O.A.C. (1995). Oil yield $\mathrm{kg} \mathrm{fed}^{-1}$ and seed husk\% were estimated as following equations:

$$
\begin{aligned}
& \text { Oil yield kg fed }{ }^{-1}=\frac{\text { Oil } \% \times \text { Seed yield fed }}{-1} \\
& \text { Seed husk }=\frac{\text { Husk weight }(\mathrm{g}) \times 100}{\text { Total seed weight }(\mathrm{g})}
\end{aligned}
$$

All obtained data were statistically analyzed according to Gomez and Gomez (1984). Means comparisons were carried out using the L.S.D. at $5 \%$ level of significance.

\section{RESULTS AND DISCUSSION:}

\section{Phosphorus level effects:}

The data in Tables $(2 \& 3)$ clearly indicate that all the studied traits plant height, head diameter, seed husk\%, seed yield plant $^{-1}$ and seed yield fed $^{-1}$ in the two growing seasons as well as stem diameter and 100 seed weight in the first season only were significantly affected with increasing phosphorus levels. The highest values in this respect were obtained with adding the highest phosphorus level (30 kg $\mathrm{P}_{2} \mathrm{O}_{5}$ fed $^{-1}$ ). These findings agreed with those obtained by Bhilegaonkar et al. (1995) and Jahangir (2006).

Data presented in Table (4) show that phosphorus fertilizer levels had no significant effect on seed oil content in the two growing seasons, while the significance increase in oil yield fed $^{-1}$ was obtained with increasing phosphorus level in the two growing seasons. The increment of obtained oil yield fed ${ }^{-1}$ could be explained through the effective role of phosphorus fertilizer in increasing seed yield 
fed $^{-1}$. These results contradict those obtained by Jahangir (2006).

\section{Plant spacing effects:}

The available data reveal that plant spacing significantly affected all studied traits in both seasons (Tables 2-4). Wide spacing produced the highest values of stem diameter, head diameter, 100-seed weight, seed husk $\%$, seed yield plant ${ }^{-1}$ and seed oil content as compared with narrow one. This may be due to the sufficient of environmental conditions in wide spacing and less competition between plants as well as increase light penetration within plant canopy which increased assimilation rate and oil formation. These results are in a good line with those obtained by Yakout et al. (1992), Sharief (1998), Allam et al. (2003), Ruffo et al. (2003), Ali and Osman (2004), Beg et al. (2007) and Tenebe et al. (2008). Reversely, plant height, seed and oil yields fed $^{-1}$ reacted to narrow spacing. This spacing produced the highest values of these traits. These results are in a good line with those obtained by Sloan et al. (2003) and El-Mohandes, Salwa, et al. (2005) on sunflower.

\section{Nitrogen level effects:}

As shown in Tables (2-4) results indicate that increasing nitrogen level from 30 to $60 \mathrm{~kg} \mathrm{~N}$ fed $^{-1}$ significantly increased all yield components in both growing seasons, except oil\%, which decreased with increasing nitrogen level. Maximum values of plant height, head diameter, stem diameter, 100-seed weight, seed husk \% , seed yield plant ${ }^{-1}$ and seed and oil yields fed $^{-1}$ were observed with adding $60 \mathrm{~kg} \mathrm{~N}^{\mathrm{N}}$ fed $^{-1}$. The increase in these characters with the increase of nitrogen level might be due to the role of nitrogen in activating the growth and yield components. Similar results were obtained by Kasem \& El-Mesilhy (1992), Salisbury and Ross (1994), Mojiri and Arzani (2003), Killi (2004) and Özer et al. (2004).

Effect of phosphorus levels (P) X plant spacing (S):

Data in Tables (5-7) show that the interaction between phosphorus (P) levels and plant spacing (S) exerted a significant effect on plant height, head diameter, seed and oil yields fed $^{-1}$ in the first season only. While, the interaction effect of $P \times S$ had significant trend on stem diameter, 100-seed weight, seed husk, seed yield plant $^{-1}$ and oil\% in both growing seasons. The highest values of plant height, seed and oil yields fed $^{-1}$ were obtained from narrow spacing receiving $30 \mathrm{~kg}_{2} \mathrm{O}_{5}$ fed $^{-1}$. On the other hand, the highest value of stem and head diameters, 100-seed weight and seed yield plant $^{-1}$ were obtained from wide spacing $(30 \mathrm{~cm})$ with $30 \mathrm{~kg}_{2} \mathrm{O}_{5}$ fed $^{-1}$. Moreover, wide spacing with $22.5 \mathrm{~kg} \mathrm{P}_{2} \mathrm{O}_{5}$ fed $^{-1}$ gave the highest values of seed husk.

\section{Effect of phosphorus levels (P) X nitrogen levels $(\mathrm{N})$ :}

Regarding phosphorus and nitrogen fertilizers $(N)$ interaction data revealed that, all studied traits were significantly affected in the both growing seasons except seed yield plant $^{-1}$ in the first season (Tables 8-10). These traits increased with increasing NP levels. The 
maximum values of plant height, stem diameter and head diameter, 100-seed weight, seed husk \%, seed yield plant $^{-1}$, seed and oil yields fed $^{-1}$ were recorded when sunflower plants were fertilized with the highest level of both elements (30 $\mathrm{P}_{2} \mathrm{O}_{5}$ and $60 \mathrm{~N} \mathrm{~kg} \mathrm{fed}{ }^{-1}$ ). While, the highest values of seed oil content were obtained by middle level of phosphorus $\left(22.5 \mathrm{~kg}_{2} \mathrm{O}_{5}\right.$ fed $\left.^{-1}\right)$ and low level of nitrogen $\left(30 \mathrm{~kg} \mathrm{Nfed}^{-1}\right)$. These results are in line with those obtained by Abdul Sadiq et al. (2000) and El Mahdi (2008).

\section{Effect of plant spacing (S) X nitrogen levels $(\mathbf{N})$ :}

The interaction between $\mathbf{S} \times \mathbf{N}$ significantly affected all studied parameters except plant height and oil\% in 2008 season and 100-seed weight in 2007 season. (Tables 11-13). In this context, the highest values of plant height and seed yield fed $^{-1}$ were obtained from plants grown at $10 \mathrm{~cm}$ plant spacing and fertilized with $60 \mathrm{~kg} \mathrm{~N}^{-1}$. Meanwhile the highest values of stem diameter, head diameter, 100-seed weight, seed husk \% and seed yield plant $^{-1}$ were produced with sowing sunflower at $30 \mathrm{~cm}$ between hills and adding $60 \mathrm{~kg} N$ fed $^{-1}$. Moreover, the highest values of oil\% were obtained from plants grown at $30 \mathrm{~cm}$ plant spacing and fertilized with $30 \mathrm{~kg} \mathrm{~N}$ fed $^{-1}$.
Effect of phosphorus levels (P) X plant spacing (S) $X$ nitrogen levels $(\mathrm{N})$ :

Furthermore, the secon order inter-action of $\mathrm{P} \times \mathrm{S} \times \mathrm{N}$ showed different trend from season to another (Tables 14-16). Plant height, stem diameter and head diameter were significantly affected in the second season. The tallest plants were obtained with fertilizing by $30 \mathrm{~kg} \mathrm{P}_{2} \mathrm{O}_{5}$ fed $^{-}$ ${ }^{1}$ and $60 \mathrm{~kg} \mathrm{~N}^{-1}$ and planting at $10 \mathrm{~cm}$. In addition, the maximum stem diameter and head diameter were obtained with fertilizing by $30 \mathrm{~kg}$ $\mathrm{P}_{2} \mathrm{O}_{5}$ fed $^{-1}$ and $60 \mathrm{~kg} \mathrm{~N}^{-1}$ and planting at 30 cm between hills.

Data prove that the second order interaction ( $\mathrm{P} \times \mathrm{S} \times \mathrm{N}$ ) had significant effect on 100-seed weight, seed husk\%, oil\%, seed yield $\mathrm{kg} \mathrm{fed}^{-1}$ in both seasons, while oil yield $\mathrm{kg} \mathrm{fed}^{-1}$ was significantly affected in the first season only. In this respect, the highest values of 100seed weight and seed husk\% were obtained by sowing sunflower plants at wide spacing with $22.5 \mathrm{~kg} \mathrm{P}_{2} \mathrm{O}_{5}$ fed $^{-1}$ and $60 \mathrm{~kg} \mathrm{~N}$ fed $^{-1}$. The highest values of seed and oil yields fed $^{-1}$ were obtained by sowing the plants at narrow spacing and fertilized with $30 \mathrm{~kg} \mathrm{P}_{2} \mathrm{O}_{5}$ fed $^{-1}$ with $60 \mathrm{~kg} \mathrm{~N}$ fed $^{-1}$. While, the highest value of oil\% was recorded by plant grown at $30 \mathrm{~cm}$ spacing and fertilized with $30 \mathrm{~kg}_{2} \mathrm{O}_{5}$ fed $^{-1}$ with $30 \mathrm{~kg} \mathrm{~N}$ fed $^{-1}$. 
Ass. Univ. Bull. Environ. Res. Vol. 13 No. 1, March 2010

$\underline{\text { See Research Tables }}$

$-16-$ 


\section{REFERENCES:}

A.O.A.C. (1995): Association of Official Analytical Chemists. Official Methods of Analysis, $16^{\text {th }}$ ed. AOAC International, Washington, D. C., USA.

Abdul Sadiq, S.; M. Shahid; A. Jan and S. Noor-Al-Din (2000): Effect of Various levels of nitrogen, phosphorus and potassium (NPK) on growth, yield and yield components of sunflower. Pakistan J. of Biological Sci. 3 (2): 338-339.

Ali, E.A. and E. B. A. Osman (2004): Effect of hill spacing fertigation using drip irrigation system in sandy calcareous soil on the productivity of some safflower genotypes. The $2^{\text {nd }}$ Syrian Egyptian Conf.

Allam, A. Y. and A. H. Galal (1996): Effect of nitrogen fertilization and plant density on yield and quality of sunflower. Assiut $\mathbf{J}$. Agric. Sci. Vol 27 (2): 169-177.

Allam, A.Y., G. R. El-Nagar and A. H. Galal (2003): Response of two sunflower hybrids to planting dates and densities. Acta Agronomica Hungarica, 51 (1): 25 35.

Al-Thabet, S.S. (2006): Effect of Plant Spacing and Nitrogen Levels on Growth and Yield of Sunflower (Helianthus Annuus L.). J. King Saud Univ., Vol. 19, Agric. Sci. (1): 1-11.

Basha, H. A. (2000): Response of two sunflower cultivars to hill spacing and nitrogen fertilizer levels under sandy soil conditions. Zagazig J. Agric. Res., 27 (2) 617-633.
Beg, A.; S.S. Pourdad and S. Alipour. (2007): Row and plant spacing effects on agronomic performance of sunflower in warm and semi-cold areas of Iran. Hella, 30 (47): 99-104.

Bhilegaonkar, M. W.; B. S. Ekshinge and B. G. Karle (1995): Effects of phosphorus, sulphur and boron levels on dry matter and grain yield of safflower. Journal of Maharashtra agricultural universities. Vol. 20 (1).

El Mahdi. A.A. (2008): Response of sesame to nitrogen and phosphorus fertilization in Northern Sudan. Proceedings of the 1st International Conference on Agricultural BioSciences. 2008. Vol. 1: 62 - 63.

El-Mohandes, Salwa, E. A. Ali and E. B. A. Osman (2005): Response of two sunflower hybrids to the number of NPK fertilizers splittings and plant densities in newly reclaimed soil. Assiut J. Agric. Sci., Vol 36 (5): 27-38.

FAS. USDA. (2008): Oil seed situation and out look.

Gomez, K.A. and A.A. Gomez (1984): Statistical Procedures for Agriculture Research. A Wiley-Inter Science Publication, John Wiley \& Sons, Inc. New York, USA.

Jahangir, A. A.; R. K. Mondal; Katrun Nada; Sadia Afoze and M.A. Hakim (2006): Response of Nitrogen and Phosphorus Fertilizer and Plant Spacing on Growth and Yield Contributing Characters of Sunflower. Bangladesh J. Sci. Ind. Res., 41(1-2): 33-40. 
Kasem, M.M. and M.A. El-Mesilhy (1992): Effect of Rates and Application Treatments of Nitrogen Fertilizer on Sunflower (Helianthus annuus L.). II. Yield and Yield Components. Annals Agric. Sci. Moshtohor, Vol. 30 (2): 665 676.

Killi, F. (2004): Influence of different nitrogen levels on productivity of oilseed and confection sunflowers (Helianthus annuus L.) under varying plant populations. International J. Agric\& Biology., Vol. 6 (4): 594-598.

Mojiri, A. and A. Arzani (2003): Effects of Nitrogen Rate and Plant Density on Yield and Yield Components of Sunflower. J. Sci. and Technol. of Agric. and Natural Resources. Vol. 7 (2): 115-125.

Özer, H.; T. Polat and E. Öztürk. (2004): Response of irrigated sunflower (Helianthus annuus L.) hybrids to nitrogen fertilization: growth, yield and yield components. Plant Soil Environ. Vol. 50 (5): 205-211.

Ruffo, M. L.; F. O. Garcia; G. A. Bollero; K. Fabrizzi and Ruiz, R. A. (2003): Nitrogen balance approach to sunflower fertilization. Communications in Soil Science and Plant Analysis. Vol. 34 (1718): 2645-2657.
Salisbury, F.B. and C.W. Ross. (1994): Plant Physiology. Belmont, California: Wadsworth Publishing Company, California Agric. Exp. Station.

Sharief, A.E. (1998): Productivity of some introduced sunflower cultivars as affected by planting date and plant population density. Zagazig J. Agric. Res., 25 (6). 895 - 909.

Sloan, R. C.; S.S. Harkness and K.L. Reel. (2003): Effect of spacing on sunflower production. Annual Report of the North Mississippi Research \& Extension Center, Mississippi Agriculture \& Forestry Experiment Station Information Bulletin 398:475-478.

Tenebe, V. A.; U. R. Pal; C. A. C. Okonkwo; and B. M. Auwalu. (2008): Response of rainfed sunflower (Helianthus annuus L.) to nitrogen rates and plant population in the semi-arid savanna region of Nigeria. J. Agronomy and Crop Science. Vol 177 (3): 207-2015.

Yakout, G. M., A. Awad, A.M. Abdel-Wahab and M. H. M. Griesh. (1992): Effect of some agronomic practices on sunflower production. 2-planting date and planting distances on yield and its components of some sunflower cultivars. Ann. Agric. Sci. Moshtohor, 30: 109-126. 


$$
\begin{aligned}
& \text { استجابة دوار الثمس للتسمبد الفوسفاتي والأزوتي } \\
& \text { تحت مسافات زر اعة مختلفة في الو ادي الجديد }
\end{aligned}
$$

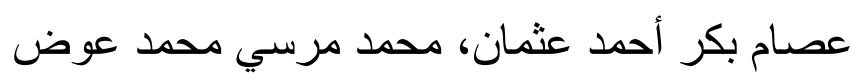

$$
\begin{aligned}
& \text { معهز بحوث المحاصيل الحقلية-مركز البحوث الزراعية }
\end{aligned}
$$

أجريت تجربتان حقليتان في المزرعة البحثية التابعة لمحطة البحوث الزراعية بمركز الخارجة - محافظة الوادي الجديد خلال الموسم الصيفي لعامي 2007 و 2008 باستخدام نظام الري بالتنقيط، بهذف دراسة استة استجابة

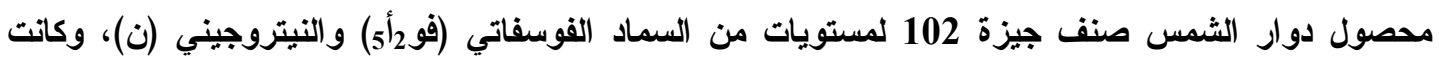
المسافات بين الجور على النمو والمحصول ومكوناته هي: 10، 20، 30 سم. كما تم إضافة السماد النيتروجيني

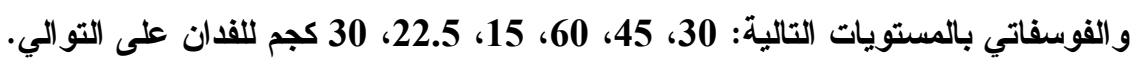

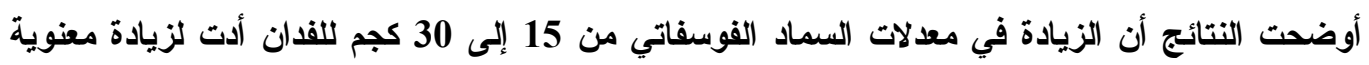

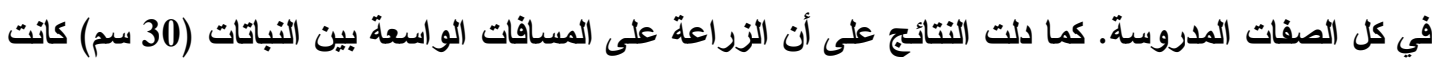
أفضل من الزراعة على المسافات الضيقة (10سم) في كل الصفات المدروسة فيما عدا صفة ارتفاع النبات ومحصول الفدان من البذور والزيت. أدى إضافة السماد النيتروجيني لتحسن ملحوظ في صفات النه النمو والمحصول، وعلى العكس حدث نقص في نسبة الزيت مع أن إضافة 60 كجم نيتروجين للفان أعطت أعلى محصول من البذور و الزيت. عامة .. يمكن التوصية بزراعة نباتات دوار الثمس صنف جيزة 102 على 10 سم بين الجور، والتسميد

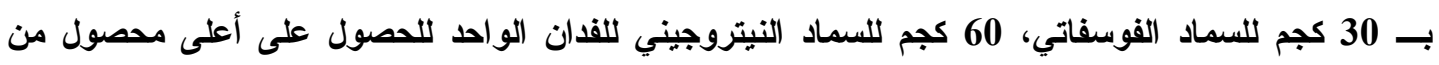
البذور والزيت تحت ظروف الو ادي الجديد. وذلك باستخدام نظام الري بالتنقيط والتسميد من خلاد مياه الري. 